\title{
Enhancement of the conversion efficiency of thin film kesterite solar cell
}

Yousaf Hameed Khattak, Faisal Baig, Shafi Ullah, Bernabé Marí, Saira Beg, and Hanif Ullah

Citation: Journal of Renewable and Sustainable Energy 10, 033501 (2018); doi: 10.1063/1.5023478

View online: https://doi.org/10.1063/1.5023478

View Table of Contents: http://aip.scitation.org/toc/rse/10/3

Published by the American Institute of Physics 


\title{
Enhancement of the conversion efficiency of thin film kesterite solar cell
}

\author{
Yousaf Hameed Khattak, ${ }^{1,2, a)}$ Faisal Baig, ${ }^{1,2, a)}$ Shafi Ullah, ${ }^{1, a)}$ \\ Bernabé Marí, ${ }^{1, a)}$ Saira Beg, ${ }^{3, a)}$ and Hanif Ullah ${ }^{2, a)}$ \\ ${ }^{1}$ Escuela de Ingeniería de Diseño, Departamento de Física Aplicada, \\ Universitat Politécnica de Valencia, Camí de Vera, Spain \\ ${ }^{2}$ Department of Electrical Engineering, Federal Urdu University of Arts, \\ Science and Technology Islamabad, Pakistan \\ ${ }^{3}$ Department of Computer Science, COMSATS Institute of Information Technology \\ Islamabad, Pakistan
}

(Received 24 January 2018; accepted 16 April 2018; published online 2 May 2018)

\begin{abstract}
$\mathrm{Cu}_{2} \mathrm{ZnSnS}_{4}(\mathrm{CZTS})$ is a non-toxic earth abundant material and a promising quaternary semiconductor compound of groups $I-I I-I V-V I$ having a kesterite symmetrical structure. Due to its optimum direct bandgap, it has been considered as a suitable material for absorber layers for photovoltaic cell applications. This paper presents the numerical simulation and modeling of CZTS based thin film kesterite photovoltaic cells using SCAP-1D software. The influence of device parameters such as the carrier concentration, thickness, densities of absorber, buffer and window layers, defect densities and the temperature effect on the performance of the $\mathrm{ZnO} / \mathrm{CdS} / \mathrm{CZTS} / \mathrm{Mo}$ photovoltaic cell structure are analyzed. Defect densities are added to the absorber layer and the interface between the buffer layer and the absorber layer. This type of solar cell does not comprise any toxic material and can lead to non-toxic thin film photovoltaic cells with outstanding optical properties. In this work, promising optimized results had been achieved with a conversion efficiency of $23.72 \%$, a fill factor of $82.54 \%$, a shortcircuit current $\left(J_{s c}\right)$ of $44.87 \mathrm{~mA} / \mathrm{cm}^{2}$, and an open circuit voltage $\left(V_{o c}\right)$ of $0.64 \mathrm{~V}$. Published by AIP Publishing. https://doi.org/10.1063/1.5023478
\end{abstract}

\section{INTRODUCTION}

Semiconductor devices play a significant role in commercial applications and can be widely used in power generation in the form of photovoltaics. Photovoltaic cells absorb the radiation of sunlight and convert it into electrical energy. ${ }^{1}$ Non-crystalline and crystalline photovoltaic cells are made from elemental and compound materials. Materials that exhibit higher conversion efficiencies are of a crystalline group, and their cost of production is higher than those of poly- and microcrystalline. Research gained more attention due to satisfactory performance, low-cost manufacturing, reliability, and stability of poly- and microcrystalline families of materials. ${ }^{2}$ For the manufacturing of solar cells, thin film technology is one of the cost-effective and efficient subjects of intense research in the photovoltaic industry. Thin-film photovoltaic cells are very suitable for low and large-scale photovoltaic cell applications. In the current scenario, economical and high-power conversion efficiency (PCE) photovoltaic devices without degradation of materials are fabricated for the generation of electricity. ${ }^{3}$ Silicon based photovoltaic cells dominated the market for many years, and due to intensification in manufacturing capabilities, thin film photovoltaic cells are gaining significance. ${ }^{4}$ For the manufacturing and production of silicon based thin film solar cells, different major deposition techniques like sputtering, thermal evaporation, molecular beam epitaxy, e-beam evaporation, close space sublimation, and metal organic chemical vapor deposition techniques are attempted. So, the cost of the material,

${ }^{\text {a)} E l e c t r o n i c ~ a d d r e s s: ~ y o u s a f . h a m e e d k @ g m a i l . c o m ~}$ 
technology, and energy consumption used by these sophisticated fabrication techniques makes the solar cell panel expensive. ${ }^{5}$

$\mathrm{Cu}(\mathrm{In}, \mathrm{Ga}) \mathrm{Se}_{2}$ (also known as $\mathrm{CIGS}$ ) and related alloy based thin-film chalcopyrite photovoltaic cells have already been presented in 2015 , on the laboratory scale, they have a conversion efficiency of about $21.7 \%$, and these types of devices have a high absorption coefficient. ${ }^{2,6}$ The commercial production of CIGS photovoltaic cells is limited because of the higher cost of using Gallium $(\mathrm{Ga})$ and Indium (In). Kesterite solar cells utilizing $\left.\mathrm{CZTS}_{(\mathrm{Cu}} \mathrm{CunSnS}_{4}\right)$ and CZTSe $\left(\mathrm{Cu}_{2} \mathrm{ZnSnSe} \mathrm{S}_{4}\right)$ and their alloys CZTSSe $\left(\mathrm{Cu}_{2} \mathrm{ZnSn}\left(\mathrm{S}_{x} \mathrm{Se}_{1-x}\right)_{4}\right)$ are emerging as the most auspicious replacement for chalcopyrite absorbers by replacing indium(In) with comparatively inexpensive Zinc $(\mathrm{Zn})$ and Gallium $(\mathrm{Ga})$ with Tin $(\mathrm{Sn})$ in the $C I G S$ absorbers. ${ }^{7-9}$ The copper zinc tin sulphide $\mathrm{Cu}_{2} \mathrm{ZnSnS}_{4}$ solar cell fabrication is very efficient and of low price for electric power generation. The outstanding features of CZTS based solar cells made it very interesting in the thin film community. For the manufacturing of a thin film photovoltaic cell, CZTS is considered as an ideal absorber material for an effective light absorber material. CZTS is a promising quaternary semiconductor compound of groups $I-I I-I V-V I$ having a kesterite symmetrical structure with a direct optical bandgap ranging from $1.4 \mathrm{eV}$ to $1.5 \mathrm{eV}$ (Refs. 10-13) and a large absorption coefficient $\alpha>10^{4} \mathrm{~cm}^{-1} \cdot{ }^{13-16}$ In 1997, the first CZTS (vacuum deposited) solar cell is reported, having a power conversion efficiency of $0.66 \% .{ }^{11} \mathrm{~A}$ conversion efficiency of $6.7 \%$ was reported for CZTS based photovoltaic solar cells in $2009 .{ }^{17}$ In 2011, the record conversion efficiency was $8.4 \% .{ }^{18}$ A conversion efficiency of $12.6 \%$ was reported for CZTSSe in 2013. ${ }^{19}$ The Shockley Queisser $(S Q)$ limit is the standard for comparing new photovoltaic technologies. It defines the maximum possible solar energy conversion efficiency for a specific material. ${ }^{20}$ According to the Shockley-Queisser limit, the optimum conversion efficiency of around $28 \%$ is theoretically possible for a CZTS based solar cell by tuning the bandgap. ${ }^{21}$ But still, it is not experimentally possible to achieve a conversion efficiency of $28 \%$ from a solar cell because of the lack of understanding of material characteristics. Numerical analysis plays a significant role in the better understanding of the material characteristics and also in the cell performance. In 2010, the reported power conversion efficiency of the CZTS/CdS structured photovoltaic cell by numerical analysis is about $7.55 \% .{ }^{6}$ A conversion efficiency of $15 \%$ was reported for the $C Z T S / C d S$ structure photovoltaic solar cell in $2016 .^{22}$ A conversion efficiency of $18.05 \%$ was presented for the $C Z T S / C d S$ structure solar cell in $2017 .^{23}$

Numerical analysis of the kesterite-based $\mathrm{ZnO} / \mathrm{CdS} / \mathrm{CZTS} /$ Mo solar cell is proposed in this work, and SCAP-1D is used for the simulation of a solar cell. Different parameters which affected the performance of a photovoltaic cell are also explained. In our simulation, the thickness of the absorber layer (CZTS) varies from $1 \mu \mathrm{m}$ to $5 \mu \mathrm{m}$ and the bandgap energy is $1.45 \mathrm{eV}$. The bandgap of the CdS buffer layer is higher than that of the absorber layer, and so, maximum photons are absorbed in CZTS. Due to this, short-circuit current $\left(\mathrm{J}_{\mathrm{sc}}\right)$ and open circuit voltage $\left(\mathrm{V}_{\mathrm{oc}}\right)$ of the solar cell increases, which also increases the overall conversion efficiency of the photovoltaic cell. The proposed results in this study will give a beneficial guideline for the designing of high performance CZTS based solar cells.

\section{SOLAR CELL DESIGN}

Figure 1 visualizes the proposed $\mathrm{ZnO} / \mathrm{CdS} / \mathrm{CZTS} / \mathrm{Mo}$ solar cell structure. Here, CdS and CZTS are the buffer and absorber layers, respectively, and they are the key elements of the proposed device. $\mathrm{ZnO}$ works as a window layer and molybdenum (Mo) as a back contact. These key elements of a device are used for determining the electrical as well as photoelectric characteristics of a solar cell. These are very helpful for the understanding of the performance of a device through numerical analysis. Solar Cell Capacitance Simulator (SCAPS-1D) program is used to analyze the performance of a photovoltaic device. The analysis is performed on the parameters like the effect of temperature variations on the performance of the photovoltaic cell, absorber layer dopant concentration and thickness, buffer layer dopant concentration and thickness, and compensation ratio, and the effect of the illumination power of the sun has been investigated. This analysis helps to achieve a conversion efficiency of $23.72 \%$. 


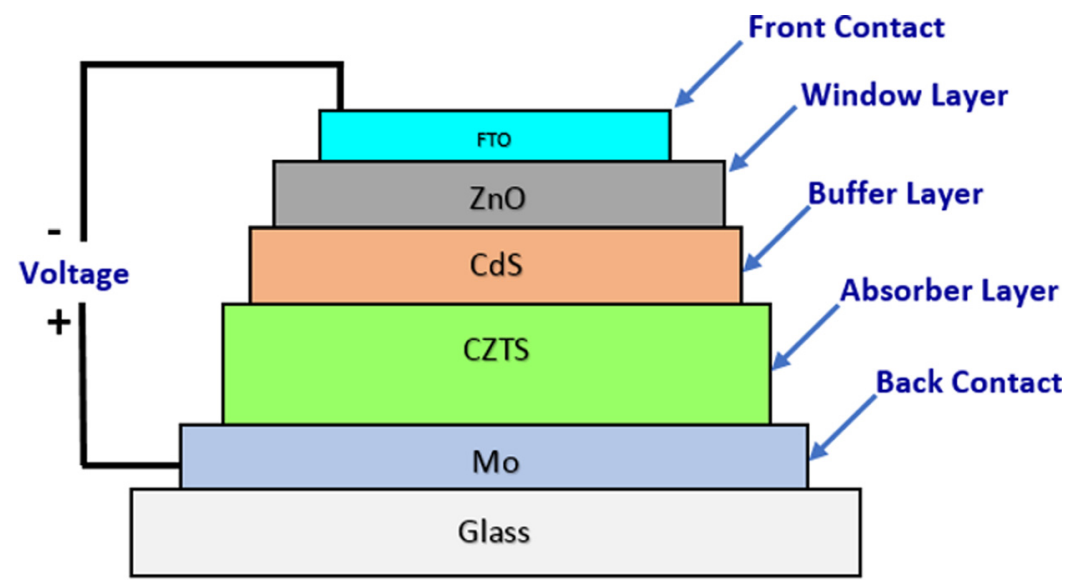

FIG. 1. Block diagram of a CZTS solar cell.

\section{NUMERICAL MODELING AND MATERIAL PARAMETERS}

For the better understanding of the performance of a device, the simulation software that can be used for the numerical analysis of the device must be able to solve the semiconductor basic equations like the continuity equation for holes and electrons and the Poisson equation relating the charge to the electrostatic potential. The charge carrier transport equation and the basic equations are well explained in the study by Simya et al. $^{24}$ Solar Cell Capacitance Simulator (SCAP1D) developed at the University of Gent, Belgium, is used to simulate the proposed solar cell. SCAP-1D is a one-dimensional simulation program for the modeling of a device. This software is designed to simulate and helps us to analyze the $J-V$ characteristic curve, ac characteristics $(C-V$ and $C-f)$, spectral response $(Q E)$ of a device, power conversion efficiency $(P C E)$, fill factor $(F F)$, short-circuit current $\left(J_{s c}\right)$, open circuit voltage $\left(V_{o c}\right)$, energy bands of materials used in the solar cell, and concentration of different materials used in solving the semiconductor basic equations, i.e., the hole and electron continuity equation and the Poisson equation. ${ }^{24-26}$

Poisson's equation used for semiconductor device simulation is

$$
\frac{\partial}{\partial x}\left(\varepsilon_{0} \varepsilon_{r} \frac{\partial \psi}{\partial x}\right)=-q\left(p-n+N_{D}^{+}-N_{A}^{-}+\frac{\rho_{d e f}}{q}\right) .
$$

The continuity equations for holes and electrons are

$$
\begin{aligned}
& -\frac{\partial J_{n}}{\partial x}-U_{n}+G=\frac{\partial_{n}}{\partial t}, \\
& -\frac{\partial J_{p}}{\partial x}-U_{p}+G=\frac{\partial_{p}}{\partial t} .
\end{aligned}
$$

Drift-diffusion equations for holes and electrons describe the carrier transport and are expressed as

$$
\begin{aligned}
& J_{n}=-\frac{\mu_{n} n}{q} \frac{\partial E_{F n}}{\partial x}, \\
& J_{p}=-\frac{\mu_{p} p}{q} \frac{\partial E_{F p}}{\partial x},
\end{aligned}
$$

where $\varepsilon_{0}$ and $\varepsilon_{r}$ are the permittivities of vacuum and the semiconductor, $\Psi$ is the electrostatic potential, $N_{A}^{-}$and $N_{D}^{+}$are the densities of ionized acceptors and donors, $p$ and $n$ are the free carrier concentrations, $\rho_{\text {def }}$ is the defect charge density, $J_{p}$ and $J_{n}$ are the hole and electron 
current densities, and $G$ is the generation rate. The continuity equation and Poisson equation with suitable boundary conditions at the contacts and interfaces result in a system of coupled differential equations in $\left(\Psi, E_{F n}, E_{F p}\right)$ or $(\Psi, n, p)$. SCAPS-1D software computes a small signal and a steady state and solution of the system. ${ }^{24,27}$

The measure of a photovoltaic cell quality is the Fill Factor $(F F)$. $F F$ is premeditated by equating the maximum power $\left(P_{\max }\right)$ to the theoretical power $\left(P_{t}\right)$ which would be output at both the short circuit current $\left(J_{s c}\right)$ and the open circuit voltage $\left(V_{o c}\right)$ as given in Eq. (6). The ratio of the energy output from the photovoltaic solar cell to the energy input from the sun is the power conversion efficiency $(P C E)$ mathematically expressed in Eq. (7)

$$
\begin{gathered}
F F=\frac{P_{\max }}{P_{t}}=\frac{V_{\max } I_{\max }}{V_{O C} J_{S C}}, \\
P C E=\frac{V_{O C} J_{S C} F F}{P_{i n}} .
\end{gathered}
$$

The parameters need to be defined are the absorber layer thickness, electron-hole mobility, intrinsic carrier concentration, electron affinity, bandgap, and doping density. For buffer and window layers, similar parameters are also required which are listed in Table I. Here, $p$ is the hole concentration, $n$ is the electron concentration in $\mathrm{cm}^{-3}$, and $W$ is the thickness in $\mu \mathrm{m} . \chi$ is the affinity in $\mathrm{eV}, E_{g}$ is the bandgap energy in $\mathrm{eV}, \mu e$ is the electron mobility in $\mathrm{cm}^{2} / \mathrm{Vs}, \mu p$ is the hole mobility in $\mathrm{cm}^{2} / \mathrm{Vs}, N_{V}$ is the valence band effective density of state, and $N_{C}$ is the conduction band effective density of states in $\mathrm{cm}^{-3}$. All the simulations are conducted under AM 1.5 illumination. The input parameters used in our numerical analysis performed are listed in Table I.

\section{RESULTS AND DISCUSSION}

\section{A. Energy band diagram}

The energy band diagram for the proposed CdS/CZTS solar cells is shown in Fig. 2. This energy band diagram is taken from the output of SCAPS for analysis purpose. The energy band diagram helps in explaining the properties of the solar cells. For incident light photons, the bandgap value that is optimal for most of the light to be absorbed for effective conversion efficiency is greater than or equal to the maximum bandgap value of $1.4 \mathrm{eV}$.

\section{B. J-V characteristics of the CdS/CZTS solar cell}

Conversion of light energy into electrical energy is the main function of the photovoltaic cell. In the dark condition, when there is no light, the photovoltaic solar cell is a large flat diode and produces the exponential $\mathrm{J}-\mathrm{V}$ curve. The cell gives an extremely smallest value of current, which is due to minority carriers in the dark condition. The solar cell starts working

TABLE I. Simulation parameters for modeling of the CZTS based kesterite solar cell. ${ }^{18,22}$

\begin{tabular}{lccc}
\hline \hline Parameters & p-CZTS (absorber layer) & n-CdS (buffer layer) & n-ZnO (window layer) \\
\hline Thickness, $\mathrm{W}(\mu \mathrm{m})$ & 4 & 0.05 & 0.2 \\
Bandgap, $\mathrm{Eg}(\mathrm{eV})$ & 1.45 & 2.4 & 3.3 \\
Electron affinity, $\chi(\mathrm{eV})$ & 4.5 & 4.5 & 4.6 \\
Dielectric permittivity, $\varepsilon_{\mathrm{r}}$ & 9 & 9 & 9 \\
Effective density of states, $\mathrm{NC}\left(\mathrm{cm}^{-3}\right)$ & $2.2 \times 10^{18}$ & $1.8 \times 10^{19}$ & $2.2 \times 10^{18}$ \\
Effective density of states, $\mathrm{NV}\left(\mathrm{cm}^{-3}\right)$ & $1.8 \times 10^{19}$ & $2.4 \times 10^{18}$ & $1.8 \times 10^{19}$ \\
Electron mobility, $\mu_{\mathrm{e}}\left(\mathrm{cm}^{2} / \mathrm{V} \mathrm{s}\right)$ & 60 & 100 & 100 \\
Hole mobility, $\mu_{\mathrm{p}}\left(\mathrm{cm}^{2} / \mathrm{V} \mathrm{s}\right)$ & 20 & 25 & 25 \\
Electron and hole concentration, $\mathrm{n}, \mathrm{p}\left(\mathrm{cm}^{-3}\right)$ & $7 \times 10^{16}$ & $1 \times 10^{17}$ & $1 \times 10^{18}$ \\
\hline \hline
\end{tabular}




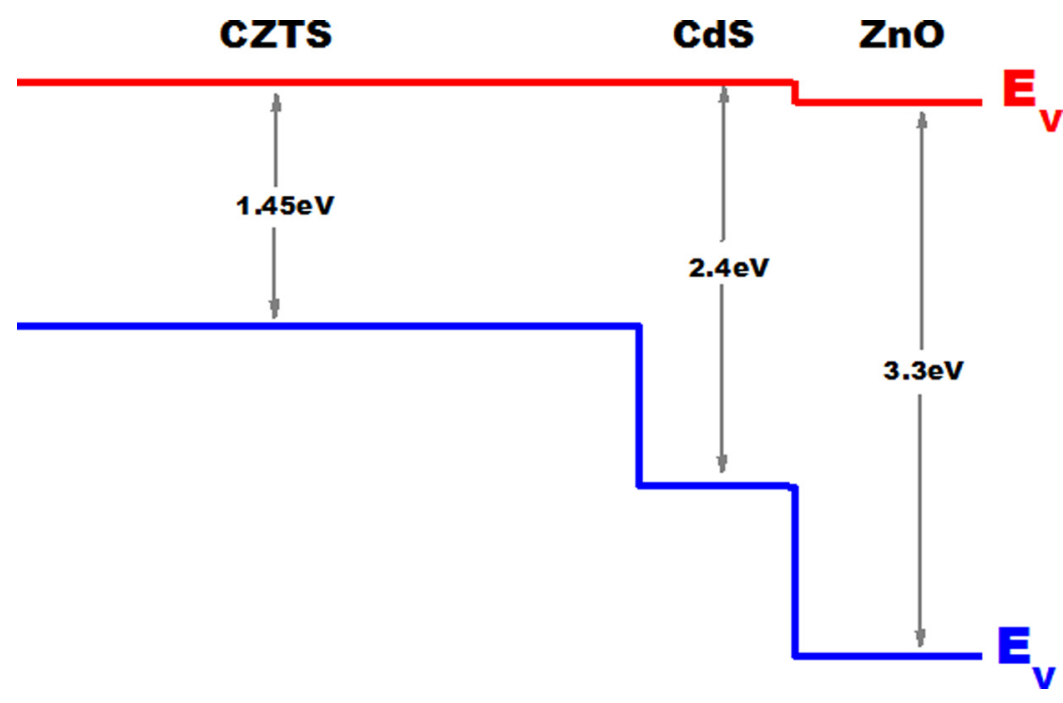

FIG. 2. Energy band illustration of the CZTS solar cell.

under the light illumination condition, and current flows due to charge carriers generated by the incidence photons. The J-V characteristic curve of the CdS/CZTS photovoltaic cell is illustrated in Fig. 3.

\section{Effect of the CZTS absorber layer thickness}

Power conversion efficiency (PCE) is directly affected by the absorber layer thickness of a device. The absorber layer (CZTS) thickness effect on photovoltaic cell performance is shown in Fig. 4. The effect of the thickness of the absorber layer is analyzed by altering the CZTS absorber layer thickness from $1 \mu \mathrm{m}-5 \mu \mathrm{m}$, while other material parameters of different layers are kept unchanged. With the increase in the thickness of an absorber layer, $\mathrm{J}_{\mathrm{SC}}$ increases with an increase in $\mathrm{V}_{\mathrm{OC}}$. PCE also increases with FF up to a point of optimal thickness. After reaching

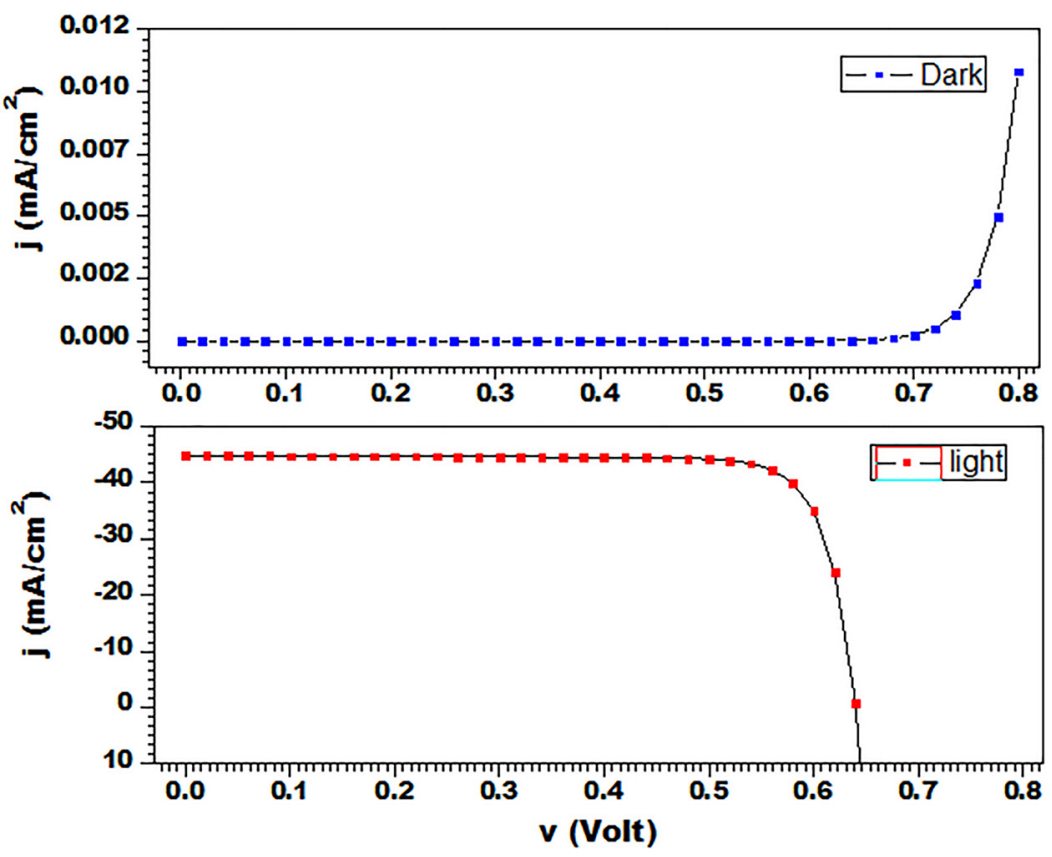

FIG. 3. Dark Vs Light J-V characteristics. 

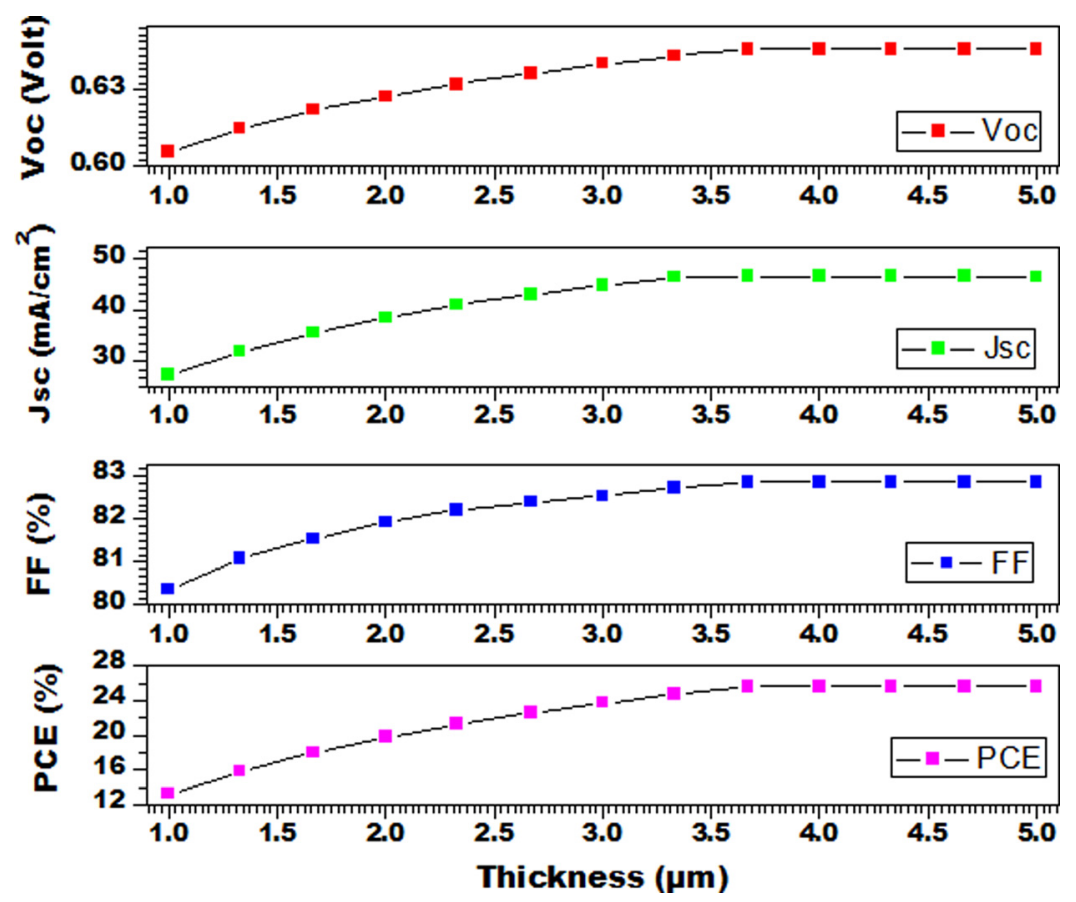

FIG. 4. Effect of the absorber layer thickness on CZTS photovoltaic cells.

the optimal values, conversion efficiency will be constant, if we further increase the thickness, PCE and FF will decrease. The increase in $\mathrm{J}_{\mathrm{SC}}$ with an increase in $\mathrm{V}_{\mathrm{OC}}$ is primarily due to more absorption of photons of longer wavelength, and this will in turn affect the ratio of photogenerated carriers. The optimal value of the thickness of the absorber layer is $4 \mu \mathrm{m}$.

\section{Effect of the acceptor concentration of the absorber layer on device performance}

The acceptor concentration simulation results are shown in Fig. 5. The acceptor concentration is varied from $1 \times 10^{15} \mathrm{~cm}^{-3}$ to $1 \times 10^{18} \mathrm{~cm}^{-3}$. Figure 5 illustrates that $\mathrm{J}_{\mathrm{sc}}$ decreases with the increase in the doping concentration, whereas $\mathrm{V}_{\mathrm{oc}}$ increases. The main reason behind is that with the increase in the acceptor carrier concentration, the saturation current of a device also increases, and then, resultantly $\mathrm{V}_{\mathrm{oc}}$ increases. $\mathrm{J}_{\mathrm{sc}}$ decreases due to the fact that the higher carrier densities will boost the recombination process and reduce the probability of the collection of the photongenerated electrons. The photons of longer wavelength having less energy are deeply absorbed in the CZTS layer. So, the collected conversion efficiency is more dependent on the influence of the concentration density. From Fig. 5, it is very clear that FF and PCE also increase with the increase in the carrier concentration in the absorber layer material. After reaching the optimal value of the acceptor carrier concentration, PCE remains constant, whereas FF and $\mathrm{V}_{\mathrm{oc}}$ decrease gradually. The optimal value taken for the acceptor carrier concentration is $7 \times 10^{17} \mathrm{~cm}^{-3}$.

\section{E. Effect of the buffer layer thickness}

The buffer layer thickness influence on the performance of a photovoltaic cell is also explored. The buffer layer thickness is varied from $0.01 \mu \mathrm{m}$ to $0.1 \mu \mathrm{m}$. Simulated fallouts are shown in Fig. 6. Figure 6 illustrates that with an increase in the buffer layer thickness, there is no change in short-circuit current $\left(\mathrm{J}_{\mathrm{sc}}\right)$, open circuit voltage $\left(\mathrm{V}_{\mathrm{oc}}\right)$, power conversion efficiency (PCE), and Fill Factor (FF). So, this result is comprehended that the change in the thickness of the buffer layer did not affect the output of the photovoltaic device. For designing a CZTS/CdS based kesterite device absorber, the optimum thickness taken is $0.3 \mu \mathrm{m}$. 


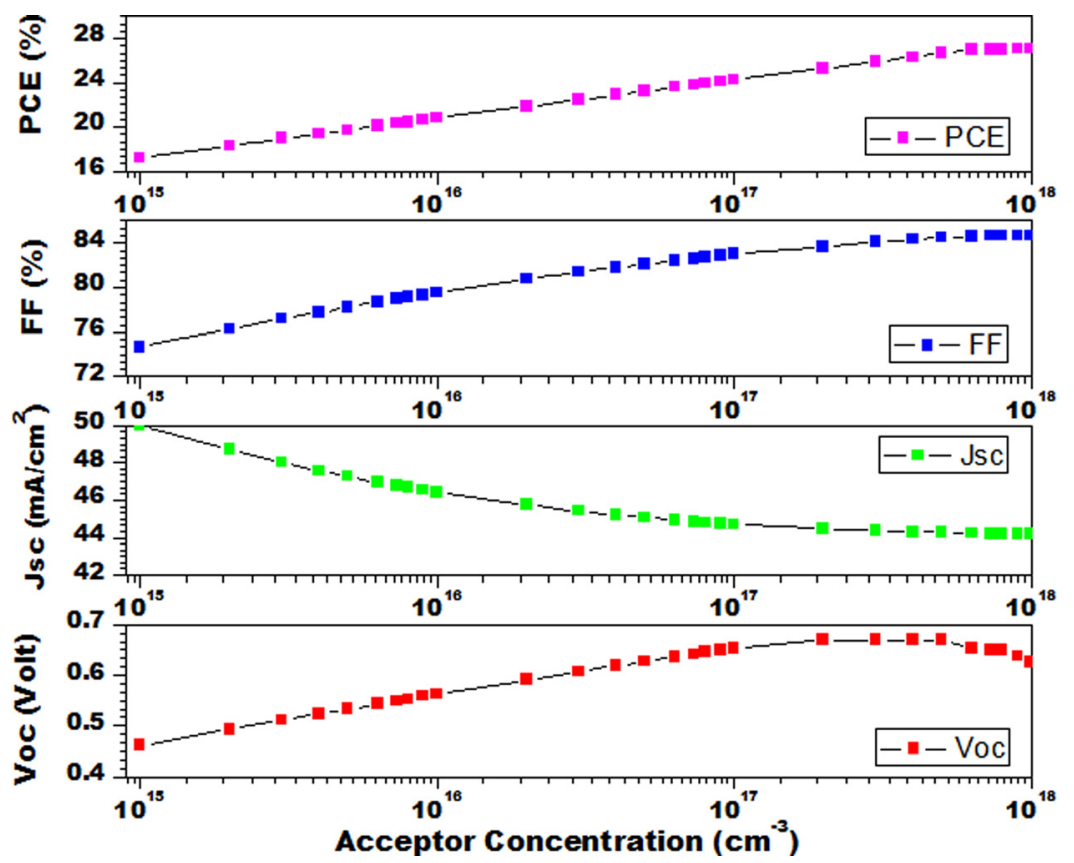

FIG. 5. Acceptor concentration in the absorber layer.

\section{F. Effect of the donor concentration of the buffer layer on device performance}

The donor concentration simulation results are shown in Fig. 7. The donor concentration is varied from $1 \times 10^{15} \mathrm{~cm}^{-3}$ to $1 \times 10^{18} \mathrm{~cm}^{-3}$. The figure illustrates that with the increase in the doping concentration, $\mathrm{J}_{\mathrm{sc}}$ and $\mathrm{V}_{\mathrm{oc}}$ almost remain constant, whereas the conversion efficiency and fill factor of a device have a slight change with the increase in the doping concentration. After reaching the optimum value, the conversion efficiency and fill factor of a device remain constant and start to decrease if we further increase the doping concentration in the buffer layer.

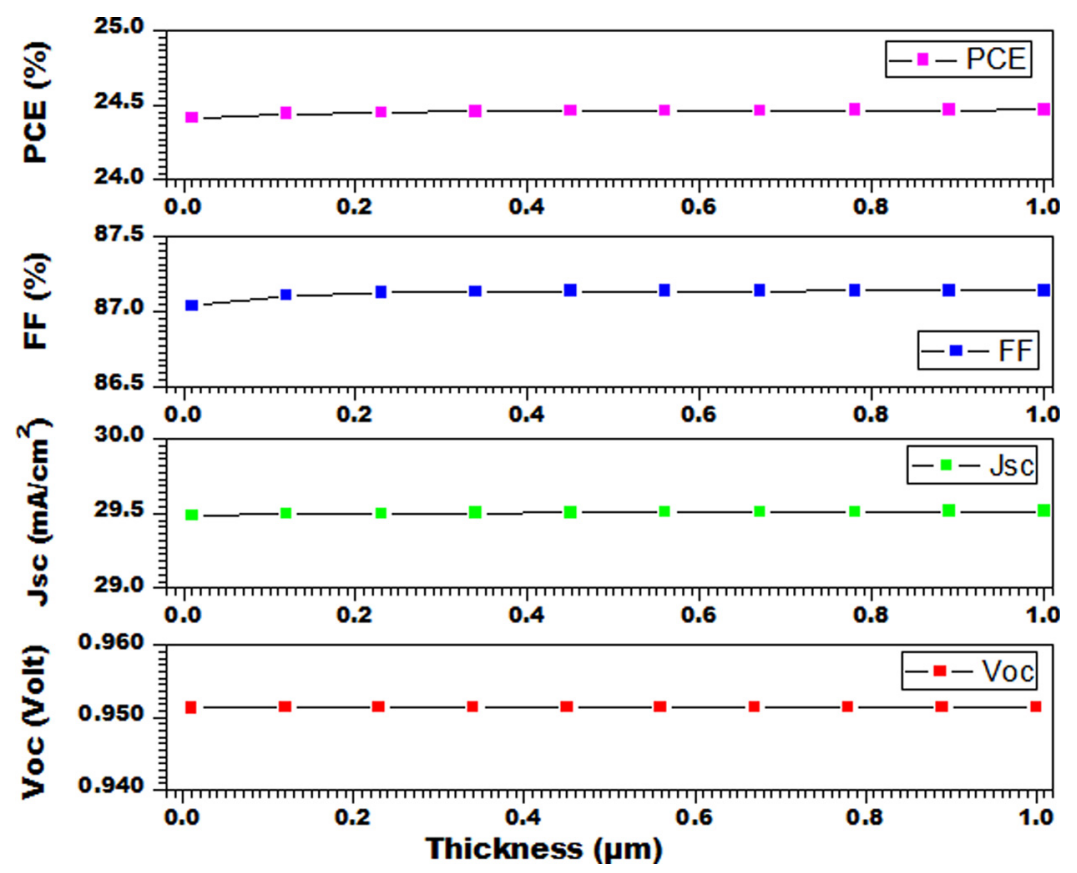

FIG. 6. Effect of the buffer layer thickness on CZTS photovoltaic cells. 


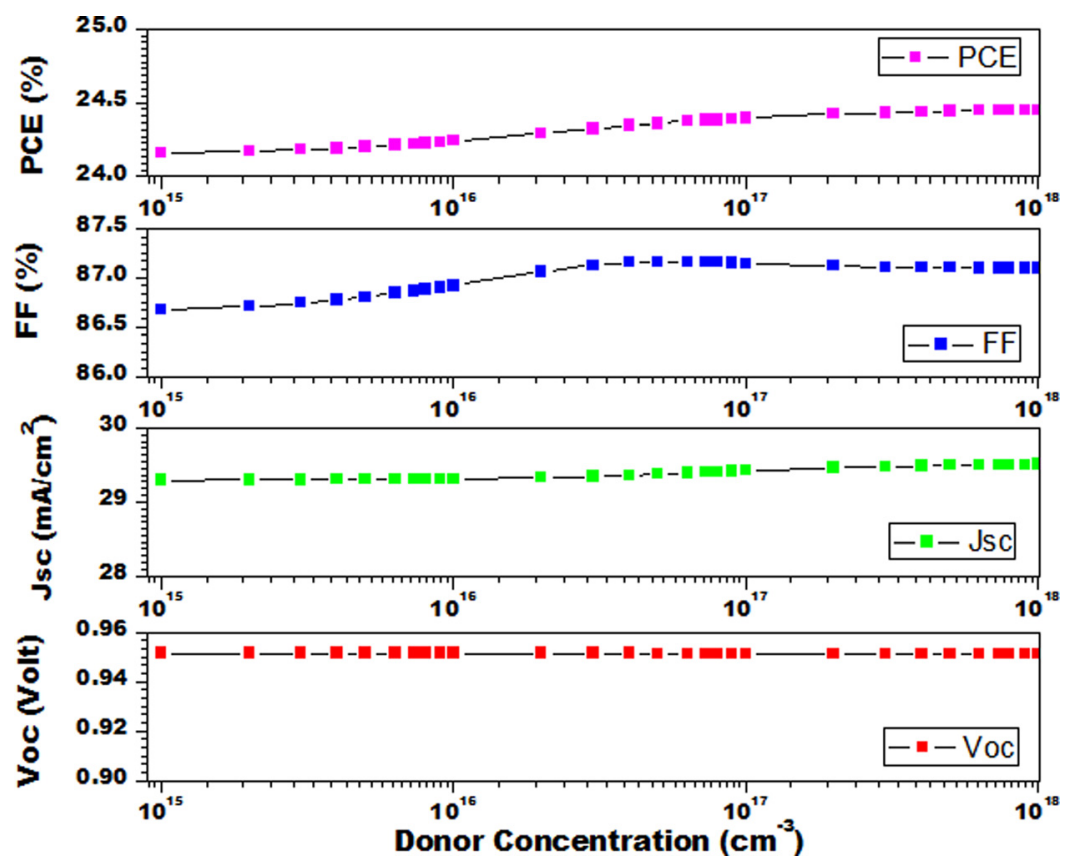

FIG. 7. Donor concentration in the buffer layer.

So, the clinched optimal concentration value of the buffer layer taken is $1 \times 10^{17} \mathrm{~cm}^{-3}$. From Fig. 7, with the increase in the doping concentration in the buffer layer, no major change is obtained, which affects the working of the device. So, this result is comprehended that the change in the concentration in the buffer layer did not affect the overall output of the photovoltaic device.

\section{G. Effect of working temperature on solar cell performance}

In the performance of photovoltaic devices, working temperature plays a significant role. The photovoltaic panels are installed in the open atmosphere. So, due to this increase in heating in the solar cell due to the sunlight, the performance of photovoltaic cells is affected. The photovoltaic cell panels are operating at a temperature greater than $300 \mathrm{~K}$. The influence of the working temperature on the proposed cell is also investigated. For investigation purpose, we take the temperature in a range of $250 \mathrm{~K}$ to $400 \mathrm{~K}$. The simulation results are shown in Fig. 8.

Open circuit voltage is directly affected by the temperature, and due to this, the overall photovoltaic cell performance is also affected. With the increase in temperature, photovoltaic cell performance decreases. Due to higher temperature, the material carrier concentration, bandgaps, and electron and hole mobilities are affected and lower conversion efficiency from a cell is achieved. ${ }^{28}$ Reverse saturation current $\mathrm{J}_{0}$ depends on the temperature due to which $\mathrm{V}_{\text {oc }}$ decreases with the increase in temperature. Reverse saturation current rises with temperature rise, and this decrease in current is the main cause for the $V_{o c}$ decrease as given in Eq. (8). ${ }^{29}$ Electrons gain more energy from the increased operating temperature. These electrons are unstable due to the higher temperature and are more likely to recombine with the holes before reaching the depletion region. Figure 8 illustrates that with the increase in temperature, the conversion efficiency of the device decreases. FF and $\mathrm{V}_{\mathrm{oc}}$ also decrease with the increase in temperature, whereas $\mathrm{J}_{\mathrm{sc}}$ increases

$$
J_{e}(V)=J_{0}\left[\exp \left(\frac{q V_{o c}}{k_{B} T}\right)-1\right]
$$



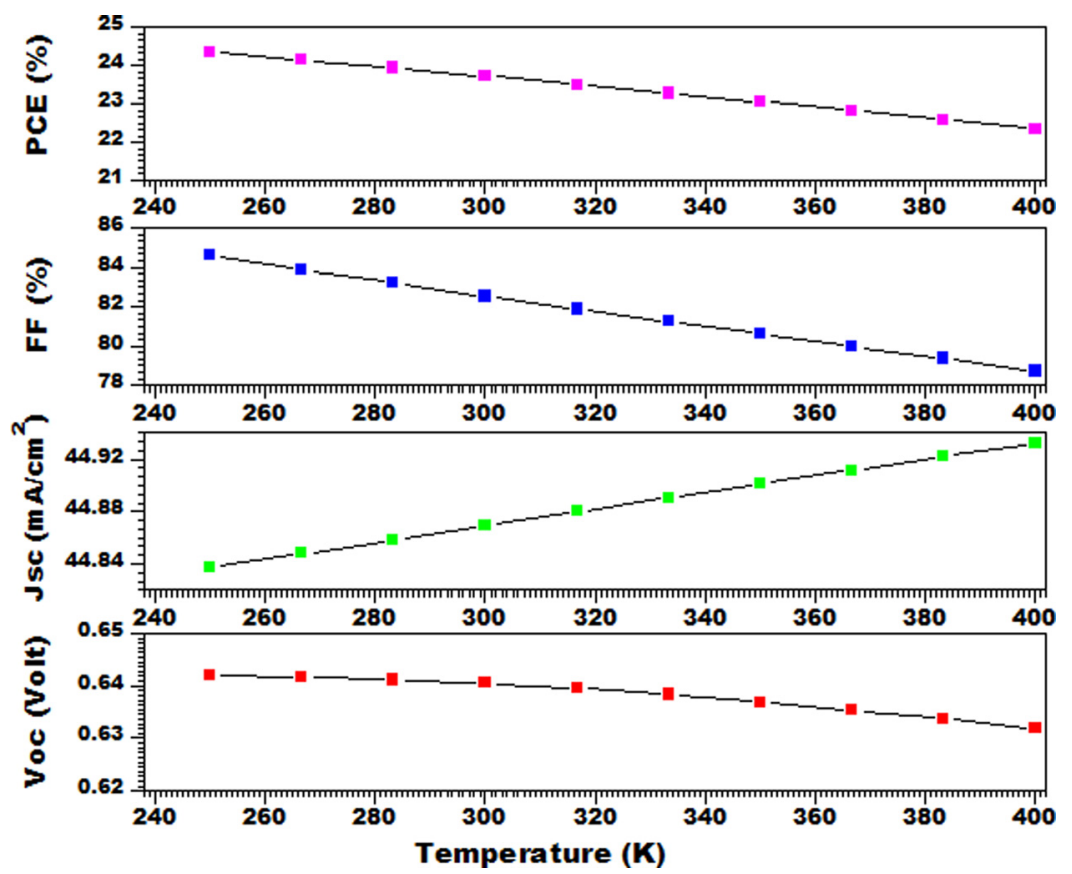

FIG. 8. Effect of temperature on the CZTS photovoltaic cell.

\section{H. Effect of defects on photovoltaic cell performance}

The effect of the absorber layer defect on photovoltaic cell performance was analyzed in this step. The density of these defects has a direct effect on the photovoltaic cell performance because with the increase in the density of defects, the minority carrier lifetime reduces, and with the reduction in the lifetime, the diffusion length of electrons and holes also reduces, thus increasing the recombination loss in the absorber layer. Figure 9 shows the effect of absorber defect density on solar cell performance.

The effect of interface defect density between CdS and CZTS on solar cell performance was observed in this step using SCAPS. The trap density at the interface will lead to surface recombination of light generated electron hole pair, and this will affect the performance of the solar cell. Figure 10 shows the result of the interface defect density effect on $\mathrm{V}_{\mathrm{oc}}$ and $\mathrm{J}_{\mathrm{sc}}$. From

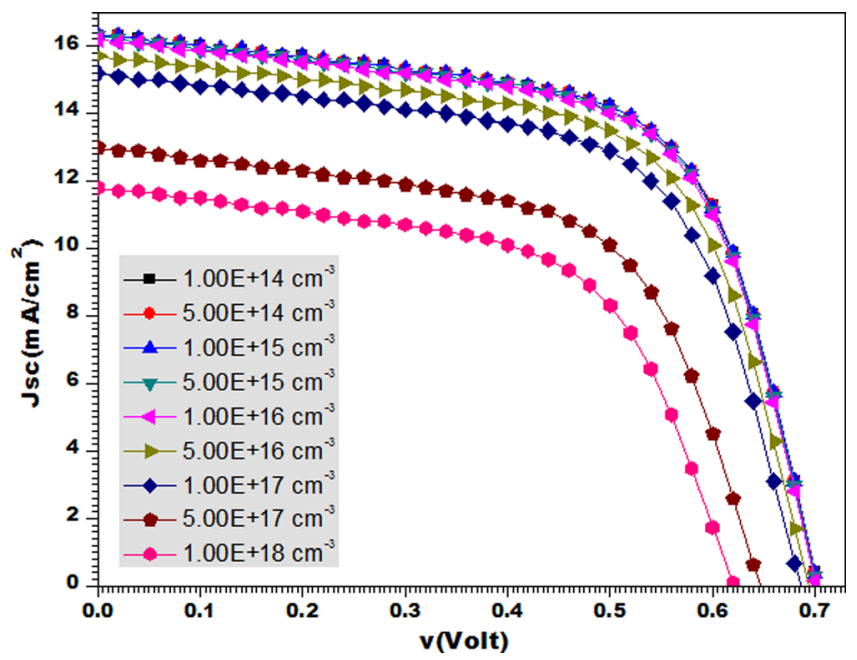

FIG. 9. Effect of the absorber layer defect on photovoltaic cell performance. 


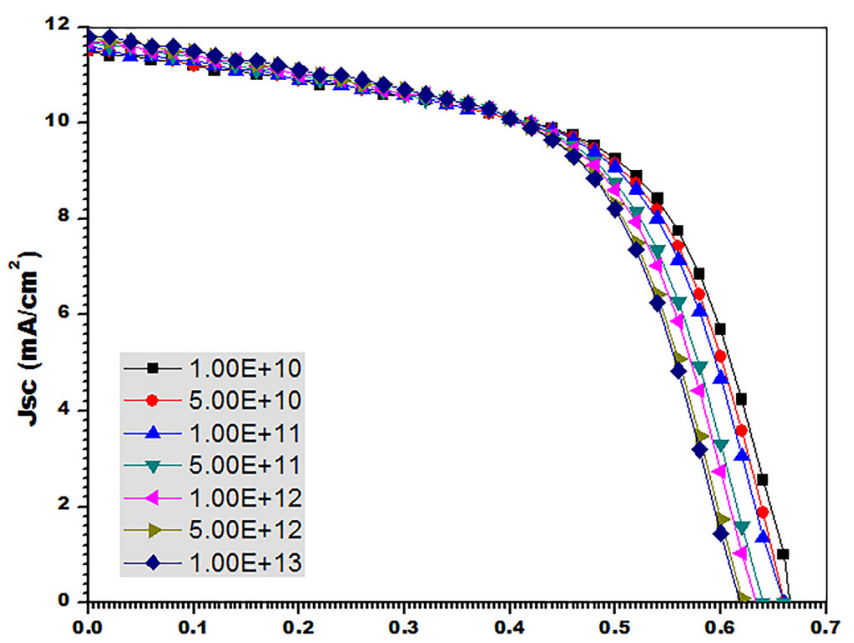

FIG. 10. Effect of interface defects on photovoltaic cell performance.

TABLE II. Defects in the CZTS absorber layer.

\begin{tabular}{lc}
\hline \hline Defect properties & Values \\
\hline Energy level with respect to reference $(\mathrm{eV})$ & 0.6 \\
Total Density $\left(1 / \mathrm{cm}^{3}\right) N_{t}$ & $1 \times 10^{15}$ \\
Capture cross-sectional area of electrons $\left(\mathrm{cm}^{2}\right) \delta_{\mathrm{e}}$ & $4.4 \times 10^{-15}$ \\
Capture cross-sectional area of holes $\left(\mathrm{cm}^{2}\right) \delta_{\mathrm{h}}$ & $4.4 \times 10^{-15}$ \\
\hline \hline
\end{tabular}

Fig. 10, it is found that increasing the density of defects will reduce the $\mathrm{V}_{\mathrm{oc}}$, but there will be a slight decrease in $\mathrm{J}_{\mathrm{sc}}$, which occurs because when interface trap defect density increases, the surface recombination also increases, and Fig. 10 shows the validation of the result of the effect of interface recombination of solar cell performance.

\section{Comparison with the experimental design solar cell results}

For the comparison of simulation results with the experimental results, the value added between the interface of CdS/CZTS is $\mathrm{N}_{\mathrm{t}}=5 \times 10^{12}\left(\mathrm{~cm}^{-2}\right)$. In Table II, the CZTS absorber layer defect is shown. ${ }^{22,30}$

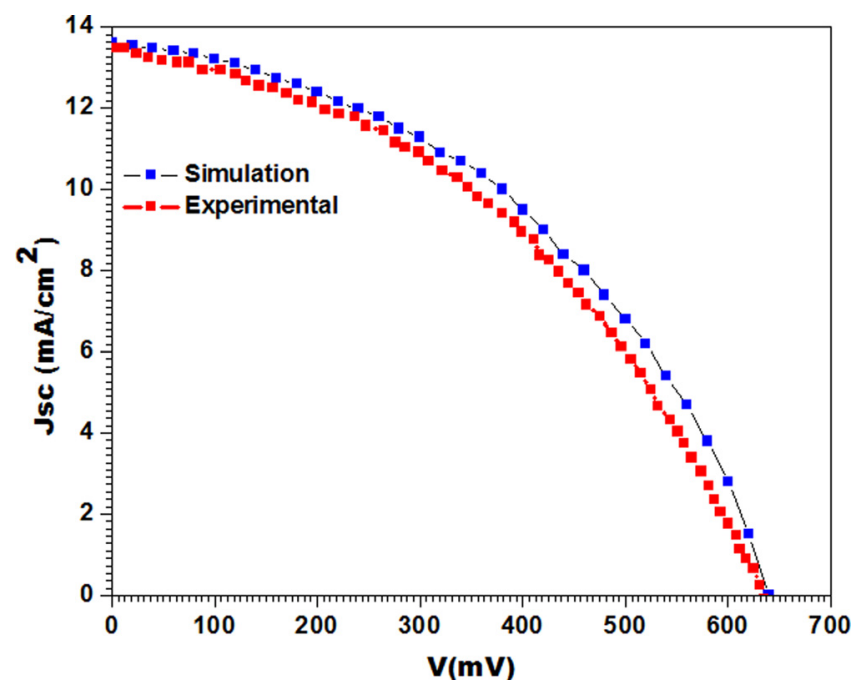

FIG. 11. Comparison of simulated results in SCAPS with experimental data presented in Ref. 31. 
TABLE III. Output performance of the experimentally stated CZTS based kesterite solar cell from the literature.

\begin{tabular}{|c|c|c|c|c|c|}
\hline Structure & $\begin{array}{l}\text { Power Conversion } \\
\text { Effeciency, PCE }(\%)\end{array}$ & $\begin{array}{c}\text { Short circuit current } \\
\text { density, } \mathrm{J}_{\mathrm{SC}}\left(\mathrm{mA} / \mathrm{cm}^{2}\right)\end{array}$ & $\begin{array}{c}\text { Open circuit } \\
\text { voltage, } V_{O C}(\mathrm{mV})\end{array}$ & $\begin{array}{l}\text { Fill factor, } \\
\text { FF }(\%)\end{array}$ & References \\
\hline $\mathrm{CZTS} / \mathrm{CdS}$ & 3.59 & 13.6 & 635 & 41.9 & 31 \\
\hline CZTS/CdS & 6.77 & 17.9 & 610 & 62 & 17 \\
\hline CZTS/CdS & 8.4 & 19.5 & 661 & 65.8 & 18 \\
\hline CZTS/CdS & 6.25 & 15.7 & 623 & 63.9 & 30 \\
\hline CZTS/CdS & 6.77 & 17.9 & 610 & 62 & 32 \\
\hline CZTS/CdS & 6.81 & 17.8 & 587 & 65 & 33 \\
\hline $\mathrm{CZTS} / \mathrm{CdS}$ & 1.3 & 7.13 & 582.4 & 32 & 34 \\
\hline CZTS/CdS & 7.1 & 21.8 & 614.3 & 55.5 & 35 \\
\hline $\mathrm{CZTS} / \mathrm{CdS}$ & 6.7 & 19.9 & 592.4 & 57.6 & 35 \\
\hline $\mathrm{CZTS} / \mathrm{CdS}$ & 4.4 & 14.6 & 572.6 & 52.2 & 35 \\
\hline $\mathrm{CZTS} / \mathrm{CdS}$ & 4.0 & 16.1 & 546.7 & 45.8 & 35 \\
\hline CZTS/CdS & 9.4 & 21.3 & 700 & 63 & 36 \\
\hline CZTS/CdS & 2.6 & 14.2 & 650 & 28 & 36 \\
\hline $\mathrm{CZTS} / \mathrm{CdS}$ & 2.35 & 12.8 & 399.2 & 45.8 & 37 \\
\hline $\mathrm{CZTS} / \mathrm{CdS}$ & 1.68 & 4.6 & 723.3 & 51 & 38 \\
\hline CZTS/CdS & 2.08 & 5.5 & 723.3 & 54 & 38 \\
\hline $\mathrm{CZTS} / \mathrm{CdS}$ & 6.44 & 17.59 & 584 & 62.89 & 39 \\
\hline $\mathrm{CZTS} / \mathrm{CdS}$ & 3.7 & 16.5 & 420 & 53 & 40 and 39 \\
\hline CZTS/CdS & 4.1 & 13 & 541 & 59.7 & 41 and 39 \\
\hline $\mathrm{CZTS} / \mathrm{CdS}$ & 4.59 & 15.44 & 545 & 54.57 & 42 \\
\hline CZTS/CdS & 4.31 & 16.34 & 518 & 50.93 & 42 \\
\hline $\mathrm{CZTS} / \mathrm{CdS}$ & 3.91 & 14.62 & 526 & 50.81 & 42 \\
\hline $\mathrm{CZTS} / \mathrm{CdS}$ & 6.77 & 17.9 & 610 & 62 & 42 and 39 \\
\hline CZTS/CdS & 7.3 & 22 & 567 & 58.1 & 43 and 39 \\
\hline
\end{tabular}

Figure 11 illustrates the results of the CdS/CZTS solar cell simulated in SCAPS with defects and compares them with the experimental result obtained in Ref. 31. After the defect study, the results from experimental work were simulated using SCAPS software to validate the proposed model. With more study of those defects, it is probable that we can enhance the efficiency of the CdS/CZTS solar cell.

TABLE IV. Output performance of the simulation based stated CZTS based kesterite solar cell from the literature.

\begin{tabular}{lccccc}
\hline \hline Structure & $\begin{array}{c}\text { Power Conversion } \\
\text { Effeciency, PCE }(\%)\end{array}$ & $\begin{array}{c}\text { Short circuit current } \\
\text { density, } \mathrm{J}_{\text {SC }}\left(\mathrm{mA} / \mathrm{cm}^{2}\right)\end{array}$ & $\begin{array}{c}\text { Open circuit } \\
\text { voltage, } \mathrm{V}_{\text {OC }}(\mathrm{mV})\end{array}$ & $\begin{array}{c}\text { Fill factor, } \\
\text { FF }(\%)\end{array}$ & Reference \\
\hline $\mathrm{CZTS} / \mathrm{CdS}$ & 8.4 & 19.5 & 749 & 57.48 & 22 \\
$\mathrm{CZTS} / \mathrm{CdS}$ & 18.05 & 25.67 & 1020 & 69.26 & 23 \\
$\mathrm{CZTS} / \mathrm{CdS}$ & 12.03 & 24.786 & 744.7 & 65.19 & 24 \\
$\mathrm{CZTS} / \mathrm{CdS}$ & 13.41 & 19.31 & 1000.2 & 69.35 & 39 \\
$\mathrm{CZTS} / \mathrm{CdS}$ & 10.4 & 20.3 & 772 & 66.5 & 44 \\
$\mathrm{CZTS} / \mathrm{CdS}$ & 8.4 & 20.3 & 661 & 62.7 & 44 \\
$\mathrm{CZTS} / \mathrm{CdS}$ & 22.63 & 51.925 & 780 & 55.83 & 45 \\
$\mathrm{CZTS} / \mathrm{ZnSe}$ & 15.90 & 48.441 & 684 & 48.00 & 45 \\
$\mathrm{CZTS} / \mathrm{CdS}$ & 10 & 23.96 & 640 & 65.2 & 46 \\
$\mathrm{CZTS} / \mathrm{CdS}$ & 23.45 & 29.23 & 1118.8 & 71.70 & 47 \\
$\mathrm{CZTS} / \mathrm{CdS}$ & 23.45 & 29.23 & 1118.8 & 71.70 & 47 \\
$\mathrm{CZTS} / \mathrm{In} \mathrm{S}_{3}$ & 11.68 & 26.66 & 770 & 56.96 & 48 \\
\hline \hline
\end{tabular}


TABLE V. Proposed results (with and without defects) of the CZTS based kesterite solar cell.

\begin{tabular}{lccccc}
\hline \hline & Structure & $\begin{array}{c}\text { Power Conversion } \\
\text { Effeciency, PCE }(\%)\end{array}$ & $\begin{array}{c}\text { Short circuit current } \\
\text { density, } \mathrm{J}_{\mathrm{SC}}\left(\mathrm{mA} / \mathrm{cm}^{2}\right)\end{array}$ & $\begin{array}{c}\text { Open circuit } \\
\text { voltage, } \mathrm{V}_{\text {OC }}(\mathrm{V})\end{array}$ & $\begin{array}{c}\text { Fill factor, } \\
\text { FF }(\%)\end{array}$ \\
\hline Without defects & CZTS/CdS & 23.72 & 44.87 & 0.64 & 82.54 \\
With defects & CZTS/CdS & 3.67 & 15.57 & 0.637 & 42.8 \\
Experimental data $^{31}$ & CZTS/CdS & 3.59 & 13.6 & 0.635 & 41.9 \\
\hline \hline
\end{tabular}

TABLE VI. Comparison of functional parameters with previous simulations.

\begin{tabular}{lccccc}
\hline \hline Structure & $\begin{array}{c}\text { Power Conversion } \\
\text { Effeciency, PCE }(\%)\end{array}$ & $\begin{array}{c}\text { Short circuit current } \\
\text { density, } \mathrm{J}_{\mathrm{SC}}\left(\mathrm{mA} / \mathrm{cm}^{2}\right)\end{array}$ & $\begin{array}{c}\text { Open circuit } \\
\text { voltage, } \mathrm{OCC}_{\mathrm{OC}}(\mathrm{V})\end{array}$ & $\begin{array}{c}\text { Fill factor, } \\
\text { FF }(\%)\end{array}$ & Reference \\
\hline $\mathrm{CZTS} / \mathrm{CdS}$ & 7.55 & 30.83 & 0.513 & 47.65 & 6 \\
$\mathrm{CZTS} / \mathrm{CdS}$ & 8.4 & 19.5 & 0.749 & 57.48 & 22 \\
$\mathrm{CZTS} / \mathrm{CdS}$ & 18.05 & 25.67 & 1.02 & 69.26 & 23 \\
$\mathrm{CZTS} / \mathrm{CdS}$ & 23.72 & 44.87 & 0.64 & 82.54 & Proposed \\
\hline \hline
\end{tabular}

TABLE VII. Comparison of physical optimized parameters with previous simulations.

\begin{tabular}{|c|c|c|c|c|}
\hline CZTS & Reference 6 & Reference 22 & Reference 23 & Proposed \\
\hline Thickness $(\mu \mathrm{m})$ & 2.2 & 0.6 & 3 & 4 \\
\hline Acceptor concentration $\left(\mathrm{cm}^{-3}\right)$ & $2 \times 10^{14}$ & $1 \times 10^{16}$ & $7 \times 10^{17}$ & $7 \times 10^{17}$ \\
\hline
\end{tabular}

The obtained results of the CdS/CZTS solar cell along with defects and without defects are given in Table V. These results are compared with the stated experimental and simulation data, which are given in Tables III and IV.

The proposed results including the defects and excluding the defects of the CZTS based kesterite solar cell are shown in Table V.

The results of our proposed simulation work with previous simulation work are given in Fig. 12 and in Tables VI and VII.

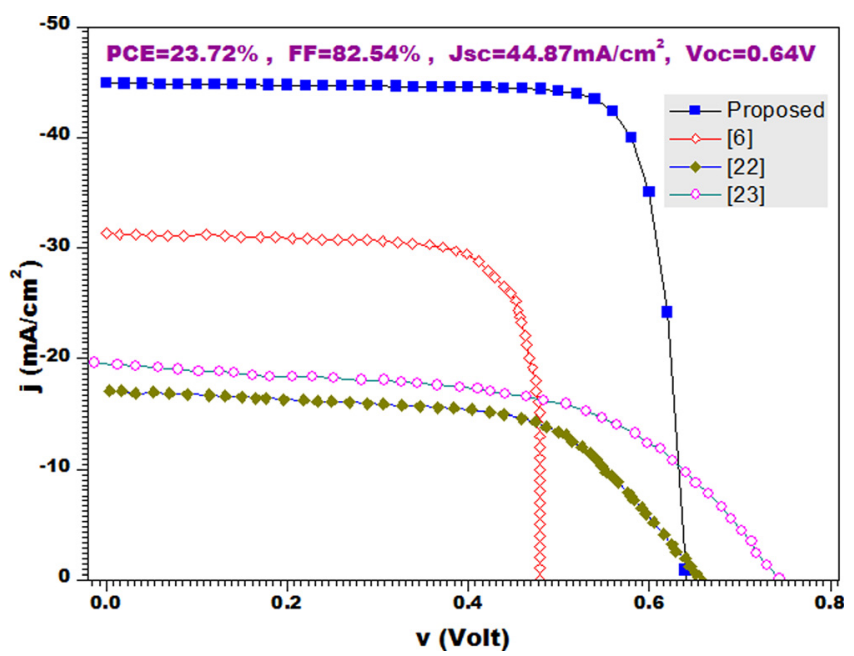

FIG. 12. Comparison with the simulated results. ${ }^{6,22,23}$ 


\section{CONCLUSION}

In this work, we simulate the kesterite based $\mathrm{ZnO}, \mathrm{CdS}$, CZTS and Mo solar cells on SCAPS software. This work is very helpful for the understanding of researchers, who are interested in the manufacturing of CZTS based kesterite solar cells. Different parameters which affected the performance of a photovoltaic cell and the conversion efficiency are explained. For the In-depth understanding of a solar cell, $\mathrm{J}-\mathrm{V}$ characteristic measures are not enough to describe the behavior of a device because the response of the solar cell also depends on its internal physical mechanism. Forgetting the confidence in the modeling of a solar cell, different characteristics, as well as different possible conditions, are to be considered for simulation. In this work, promising optimized results had been achieved with a conversion efficiency of $23.72 \%$, a fill factor $(\mathrm{FF})$ of $82.54 \%$, a short-circuit current $\left(\mathrm{J}_{\mathrm{sc}}\right)$ of $44.87 \mathrm{~mA} / \mathrm{cm}^{2}$, and an open circuit voltage $\left(\mathrm{V}_{\mathrm{oc}}\right)$ of $0.64 \mathrm{~V}$. The results will give important guidance for the feasible fabrication of higher efficiency CZTS based photovoltaic cells. From the accomplished results, it is clear that improved performance can be achieved from the solar cell and numerical modeling plays a significant role.

\section{ACKNOWLEDGMENTS}

This work was supported by Ministerio de Economía y Competitividad (ENE2016-77798C4-2-R) and Generalitat valenciana (Prometeus 2014/044).

${ }^{1}$ I. Rimmaudo, A. Salavei, and A. Romeo, "Effects of activation treatment on the electrical properties of low temperature grown CdTe devices," Thin Solid Films. 535, 253-256 (2013).

${ }^{2}$ M. A. Green, K. Emery, Y. Hishikawa, W. Warta, and E. D. Dunlop, "Solar cell efficiency tables (Version 45)," Prog. Photovoltaics Res. Appl. 23, 1-9 (2015).

${ }^{3} \mathrm{~K}$. Jimbo et al., " $\mathrm{Cu}_{2} \mathrm{ZnSnS}_{4}$-type thin film solar cells using abundant materials," Thin Solid Films 515, 5997-5999 (2007).

${ }^{4}$ S. Hegedus, "Thin film solar modules: The low cost, high throughput and versatile alternative to Si wafers," Prog. Photovoltaics Res. Appl. 14, 393-411 (2006)

${ }^{5}$ A. Mutalikdesai and S. K. Ramasesha, "Solution process for fabrication of thin film CdS/CdTe photovoltaic cell for building integration," Thin Solid Films 632, 73-78 (2017).

${ }^{6}$ N. Amin, M. I. Hossain, P. M. Chelvanathan, A. S. M. Uzzaman, and K. Sopian, "Prospects of Cu2ZnSnS4(CZTS) solar cells from numerical analysis," in International Conference on Electrical \& Computer Engineering (ICECE 2010) (IEEE, 2010), Vol. 4, pp. 730-733.

${ }^{7}$ I. L. Repins et al., "Kesterite Successes, Ongoing Work, and Challenges: A Perspective From Vacuum Deposition," IEEE J. Photovoltaics 3, 439-445 (2013).

${ }^{8} \mathrm{H}$. Wang et al., "Multifunctional TiO2 nanowires-modified nanoparticles bilayer film for 3D dye-sensitized solar cells," Optoelectron. Adv. Mater. Rapid Commun.Vol. 4, 1166-1169 (2010).

${ }^{9}$ H. Zhou et al., "CZTS nanocrystals: A promising approach for next generation thin film photovoltaics," Energy Environ. Sci. 6, 2822 (2013).

${ }^{10}$ J. SEOL, S. LEE, J. LEE, H. NAM, and K. KIM, "Electrical and optical properties of CuZnSnS thin films prepared by rf magnetron sputtering process," Sol. Energy Mater. Sol. Cells 75, 155-162 (2003).

${ }^{11} \mathrm{H}$. Katagiri et al., "Preparation and evaluation of $\mathrm{Cu} 2 \mathrm{ZnSnS4}$ thin films by sulfurization of E-B evaporated precursors," Sol. Energy Mater. Sol. Cells 49, 407-414 (1997).

${ }^{12} \mathrm{~K}$. Tanaka, N. Moritake, and $\mathrm{H}$. Uchiki, "Preparation of $\mathrm{Cu}_{2} \mathrm{ZnSnS}_{4}$ thin films by sulfurizing sol-gel deposited precursors," Sol. Energy Mater. Sol. Cells 91, 1199-1201 (2007).

${ }^{13} \mathrm{H}$. Wei, W. Guo, Y. Sun, Z. Yang, and Y. Zhang, "Hot-injection synthesis and characterization of quaternary $\mathrm{Cu}_{2} \mathrm{ZnSnSe}_{4}$ nanocrystals," Mater. Lett. 64, 1424-1426 (2010).

${ }^{14}$ D. B. Mitzi, O. Gunawan, T. K. Todorov, K. Wang, and S. Guha, "The path towards a high-performance solution-processed kesterite solar cell,” Sol. Energy Mater. Sol. Cells 95, 1421-1436 (2011).

${ }^{15}$ C. P. Chan, H. Lam, and C. Surya, "Preparation of $\mathrm{Cu}_{2} \mathrm{ZnSnS}_{4}$ films by electrodeposition using ionic liquids," Sol. Energy Mater. Sol. Cells 94, 207-211 (2010).

${ }^{16} \mathrm{X}$. Wu, W. Liu, S. Cheng, Y. Lai, and H. Jia, "Photoelectric properties of $\mathrm{Cu} 2 \mathrm{ZnSnS} 4$ thin films deposited by thermal evaporation," J. Semicond. 33, 22002 (2012).

${ }^{17}$ H. Katagiri et al., "Development of CZTS-based thin film solar cells," Thin Solid Films 517, 2455-2460 (2009).

${ }^{18}$ B. Shin et al., "Thin film solar cell with $8.4 \%$ power conversion efficiency using an earth-abundant $\mathrm{Cu}_{2} \mathrm{ZnSnS}_{4}$ absorber," Prog. Photovolt. Res. Appl. 21, 72-76 (2013).

${ }^{19}$ W. Wang et al., "Device Characteristics of CZTSSe Thin-Film Solar Cells with 12.6\% Efficiency," Adv. Energy Mater. 4, 1301465 (2014).

${ }^{20}$ Y. Xu, T. Gong, and J. N. Munday, “The generalized Shockley-Queisser limit for nanostructured solar cells,” Sci. Rep. 5, 13536 (2015).

${ }^{21}$ W. Shockley and H. Queisser, "J. Detailed Balance Limit of Efficiency of p-n Junction Solar Cells," J. Appl. Phys. 32, 510-519 (1961). 
${ }^{22}$ M. Djinkwi Wanda, S. Ouédraogo, F. Tchoffo, F. Zougmoré, and J. M. B. Ndjaka, "Numerical Investigations and Analysis of $\mathrm{Cu}_{2} \mathrm{ZnSnS}_{4}$ Based Solar Cells by SCAPS-1D," Int. J. Photoenergy 2016, 1-9.

${ }^{23}$ A. D. Adewoyin, M. A. Olopade, and M. Chendo, "Enhancement of the conversion efficiency of Cu2ZnSnS4 thin film solar cell through the optimization of some device parameters. Opt," Int. J. Light Electron Opt. 133, 122-131 (2017).

${ }^{24}$ O. K. Simya, A. Mahaboobbatcha, and K. Balachander, "A comparative study on the performance of Kesterite based thin film solar cells using SCAPS simulation program," Superlattices Microstruct. 82, 248-261 (2015).

${ }^{25}$ A. Niemegeers and M. Burgelman, "Numerical modelling of AC-characteristics of CdTe and CIS solar cells," in Conference Record of the Twenty Fifth IEEE Photovoltaic Specialists Conference - 1996 (IEEE, 1996), pp. 901-904.

${ }^{26}$ K. Decock, P. Zabierowski, and M. Burgelman, "Modeling metastabilities in chalcopyrite-based thin film solar cells," J. Appl. Phys. 111, 043703 (2012).

${ }^{27}$ H. Movla, "Optimization of the CIGS based thin film solar cells: Numerical simulation and analysis," Optik (Stuttg) $\mathbf{1 2 5}$, 67-70 (2014)

${ }^{28}$ M. S. Hossain, N. Amin, M. A. Matin, M. M. Aliyu, T. Razykov, and K. Sopian, "A numerical study on the prospects of high efficiency ultra thin $\mathrm{Zn}_{\mathrm{x}} \mathrm{Cd}_{1-\mathrm{x}} \mathrm{S} / \mathrm{CdTe}$ solar cell," Chalcogenide Lett. 8, 263-272 (2011).

${ }^{29}$ W. E. I. Sha, X. Ren, L. Chen, and W. C. H. Choy, "The efficiency limit of CH 3 NH 3 PbI 3 perovskite solar cells," Appl. Phys. Lett. 106, 221104 (2015).

${ }^{30} \mathrm{~L}$. Yin et al., "Limitation factors for the performance of kesterite $\mathrm{Cu}_{2} \mathrm{ZnSnS}_{4}$ thin film solar cells studied by defect characterization," RSC Adv. 5, 40369-40374 (2015).

${ }^{31} \mathrm{Z}$. Li et al., "A simple structure of $\mathrm{Cu}_{2} \mathrm{ZnSnS}_{4} / \mathrm{CdS}$ solar cells prepared by sputtering," Phys. B: Condens. Matter 526, 80-83 (2017).

${ }^{32}$ S. Chen, A. Walsh, X. Gong, and S. Wei, "Classification of lattice defects in the kesterite $\mathrm{Cu}_{2} \mathrm{ZnSnS}_{4}$ and $\mathrm{Cu}_{2} \mathrm{ZnSnSe}_{4}$ earth-abundant solar cell absorbers," Adv. Mater. 25, 1522-1539 (2013).

${ }^{33} \mathrm{~K}$. Wang et al., "Thermally evaporated $\mathrm{Cu}_{2} \mathrm{ZnSnS}_{4}$ solar cells," Appl. Phys. Lett. 97, 143508 (2010).

${ }^{34}$ E. Kask, T. Raadik, M. Grossberg, R. Josepson, and J. Krustok, "Deep defects in $\mathrm{Cu}_{2} \mathrm{ZnSnS}_{4}$ monograin solar cells," Energy Procedia 10, 261-265 (2011).

${ }^{35}$ J. Tao et al., "7.1\% efficient co-electroplated $\mathrm{Cu}_{2} \mathrm{ZnSnS}_{4}$ thin film solar cells with sputtered CdS buffer layers," Green Chem. 18, 550-557 (2016).

${ }^{36} \mathrm{~S}$. Tajima, M. Umehara, M. Hasegawa, T. Mise, and T. Itoh, " $\mathrm{Cu}_{2} \mathrm{ZnSnS}_{4}$ photovoltaic cell with improved efficiency fabricated by high-temperature annealing after CdS buffer-layer deposition," Prog. Photovoltaics Res. Appl. 25, 14-22 (2017).

${ }^{37}$ M. G. Sousa et al., "Optimization of post-deposition annealing in $\mathrm{Cu}_{2} \mathrm{ZnSnS}_{4}$ thin film solar cells and its impact on device performance," Sol. Energy Mater. Sol. Cells 170, 287-294 (2017).

${ }^{38}$ S. Mahajan et al., "Low cost nanostructure kesterite CZTS thin films for solar cells application," Mater. Lett. 210, 92-96 (2018).

${ }^{39} \mathrm{M}$. Patel and A. Ray, "Enhancement of output performance of $\mathrm{Cu}_{2} \mathrm{ZnSnS}_{4}$ thin film solar cells-A numerical simulation approach and comparison to experiments," Phys. B: Condens. Matter 407, 4391-4397 (2012).

${ }^{40} \mathrm{~N}$. Momose et al., " $\mathrm{Cu}_{2} \mathrm{ZnSnS}_{4}$ thin film solar cells utilizing sulfurization of metallic precursor prepared by simultaneous sputtering of metal targets," Jpn. J. Appl. Phys., Part 1 50, 01 BG09 (2011).

${ }^{41}$ B.-A. Schubert et al., "C $\mathrm{Cu}_{2} \mathrm{ZnSnS}_{4}$ thin film solar cells by fast coevaporation," Prog. Photovoltaics Res. Appl. 19, $93-96$ (2011).

${ }^{42} \mathrm{H}$. Katagiri et al., "Enhanced conversion efficiencies of $\mathrm{Cu}_{2} \mathrm{ZnSnS}_{4}$-based thin film solar cells by using preferential etching technique," Appl. Phys. Express 1, 41201 (2008).

${ }^{43}$ S. Ahmed et al., "A High Efficiency Electrodeposited $\mathrm{Cu}_{2} \mathrm{ZnSnS}_{4}$ Solar Cell," Adv. Energy Mater. 2, 253-259 (2012).

${ }^{44} \mathrm{M}$. Courel, J. A. Andrade-Arvizu, and O. Vigil-Galán, "Towards a CdS/Cu $2 \mathrm{ZnSnS} 4$ solar cell efficiency improvement: A theoretical approach," Appl. Phys. Lett. 105, 233501 (2014).

${ }^{45}$ R. Mahbub, M. S. Islam, F. Anwar, S. S. Satter, and S. M. Ullah, "Simulation of CZTS thin film solar cell for different buffer layers for high efficiency performance," South Asian J. Eng. Technol. 2, 1-10 (2016).

${ }^{46}$ A. Cherouana and R. Labbani, "Study of CZTS and CZTSSe solar cells for buffer layers selection," Appl. Surf. Sci. 424, $251-255$ (2017).

${ }^{47}$ M. W. Rahman, S. M. Abdullah, M. A. Bakth, Q. N. U. Islam, and M. A. Hoque, "Numerical analysis of stacked layered CZTS and CZTSe-based thin film solar cell," International Conference on Electrical, Computer and Communication Engineering (2017), pp. 115-118.

${ }^{48}$ A. Shama, M. Miraz, M. Faruk, and M. A. Rahman, "Numerical analysis of deep level defects in $\mathrm{Cu}_{2} \mathrm{ZnSnS}_{4}(\mathrm{CZTS})$ thin film solar cells," IEEE 4, 0-5 (2015).10.1109/ICGET.2015.7315094 